\title{
ОРГАНОЛЕПТИЧЕСКАЯ ОЦЕНКА И СОДЕРЖАНИЕ БЕНЗПИРЕНА В МЯСНЫХ ПАШТЕТАХ, ОБОГАЩЕННЫХ БЕЛКОВО- МИНЕРАЛЬНЫМ КОМПОНЕНТОМ ВТОРИЧНОГО РЫБНОГО СЫРЬЯ ГОРЯЧЕГО КОПЧЕНИЯ
}

\author{
К. А. Степанова, студентка \\ e-mail: stepanova_kld@mail.ru \\ ФГБОУ ВО «Калининградский государственный \\ технический университет»
}

В статье отражены результаты работы по оценке образцов мясного паштета, обогащенного белково-минеральным компонентом вторичного рыбного сырья горячего копчения. Дана сравнительная характеристика образцов паштета по органолептическим показателям, функциональным свойствам и их безопасности по содержанию бензпирена. Определена оптимальная дозировка белково-минерального комплекса для введения в рецептуру паштета. Установлен предельно допустимый уровень бензпирена в белковоминерального комплексе.

Ключевые слова: мясной паштет, белково-минеральный комплекс, кальций, органолептические показатели, бензпирен

\section{ВВЕДЕНИЕ}

Актуальным направлением развития пищевой и перерабатывающей промышленности Российской Федерации является переход к ресурсосберегающим технологиям, обеспечивающим безотходное производство и производство с минимальным воздействием на экологию. В частности, важным направлением является повышение степени переработки водных биоресурсов. Вторичное рыбное сырье является источником ценных биологически активных компонентов: полноценных белков, минеральных веществ, а также липидов, богатых полиненасыщенными жирными кислотами.

Калининградская область является лидером российского рынка по производству рыбных консервов, в том числе консервов типа «Шпроты в масле». В процессе выработки консервов данного вида за год на предприятиях области накапливается более 3,5 тыс. тонн отходов - голов и хвостовых плавников кильки и салаки горячего копчения [1]. Из-за содержания в рыбе горячего копчения коптильных компонентов, включая полициклические ароматические углеводороды (ПАУ) и фенольные соединения, они не могут быть использованы для переработки на кормовую продукцию, в связи с чем подвергаются утилизации.

Актуальной является реализация функциональных компонентов вторичного пищевого сырья через товары массового потребления. К таковым относятся, например, вареные колбасные изделия. Обогащение традиционных продуктов добавками на основе вторичного пищевого сырья повышает полезные свойства продукции, расширяет ассортимент и благоприятно сказывается на экономической и экологической составляющих жизни общества. 


\section{ОБЪЕКТ ИССЛЕДОВАНИЯ}

Объектом настоящего исследования является мясной паштет, обогащенный белковоминеральным комплексом (БМК) из вторичного рыбного сырья горячего копчения, предназначенный для питания людей с нарушениями фосфорно-кальциевого обмена. Для эксперимента приготавливали образцы паштета с содержанием БМК в количестве 3 \%, 5 \% и $7 \%$.

Технология переработки вторичного рыбного сырья и получения белковоминерального комплекса разработана учеными кафедры Пищевой биотехнологии ФГБОУ BO «КГТУ» совместно с фирмой «ANiMOX» из Германии [2]. В настоящей работе в качестве обогащающего компонента используется белково-минеральный комплекс из голов копченой кильки - отхода производства консервов «Шпроты в масле».

\section{ЦЕЛЬ И ЗАДАЧИ ИССЛЕДОВАНИЯ}

Целью работы явилась оптимизация рецептуры мясного паштета, обогащенного белково-минеральным комплексом из вторичного рыбного сырья горячего копчения.

Для достижения поставленной цели решались следующие задачи:

- проведение сравнительной характеристики образцов паштетов по органолептическим показателям;

- определение дозировки белково-минерального комплекса, необходимой для создания функционального мясного паштета;

- оценка образцов паштета по содержанию бензпирена в них;

- определение оптимальной дозировки белково-минерального комплекса в рецептуре паштета с учетом совокупности факторов.

\section{МЕТОДЫ ИССЛЕДОВАНИЯ}

Органолептическая оценка образцов проводилась по 5-балльной шкале в соответствии с требованиями ГОСТ 9959-2015 «Мясо и мясные продукты. Общие условия проведения органолептической оценки». Оценке подвергались следующие показатели: внешний вид, консистенция, вид и цвет на разрезе, вкус и запах.

Для наиболее точной характеристики вкуса образцов обогащенного мясного паштета был использован профильный метод. Вкус был разбит на составляющие, которые могут характеризовать продукт: соленый, пряный, копченый, рыбный и горький вкусы.

В целях определения содержания кальция в образцах паштетов проводилось его определение в БМК по ГОСТ 26570-95 «Корма, комбикорма, комбикормовое сырье. Методы определения кальция». Содержание кальция в образцах паштета устанавливалось расчетным путем с учетом вклада всех компонентов рецептуры.

В БМК и головах кильки горячего копчения определялось содержание бенпирена по ФР.1.31.2008.01033 [3] на базе Лабораторного центра «АтлантНИРО». На основе полученных данных рассчитывалось содержание бензпирена в образцах паштета.

\section{РЕЗУЛЬТАТЫ ИССЛЕДОВАНИЯ}

Белково-минеральный комплекс представляет собой рассыпчатый, тонкоизмельченный порошок серо-коричневого цвета с ароматом копченой рыбы. В образцах с содержанием БМК, составляющим $3 \%$, вкус добавки практически не ощущался. Введение БМК в количестве $5 \%$ дает умеренно выраженный вкус и аромат копченой рыбы, что является приемлемым отличительным свойством паштета нового вида. Помимо влияния на вкусовые характеристики и запах паштета БМК изменяет цвет продукта 
в сторону серо-коричневого, более темного цвета. Образец с содержанием БМК в количестве 7 \% получил самую низкую оценку органолептических свойств в связи с наличием четко выраженного вкуса копченой рыбы и темно-коричневого цвета паштетной массы.

Белково-минеральный комплекс содержит порядка 55 \% белка, за счет чего имеет хорошую степень набухания, которая составила 75 \%. Соответственно, гидромодуль БМК составляет 1:0,75. Данные по степени набухания позволяют корректировать консистенцию паштета посредством увеличения доли куриного бульона пропорционально содержанию БМК. Структурно-механические свойства паштета формируются также с помощью вспомогательных компонентов рецептуры: муки пшеничной и молока сухого, обладающих хорошей влагоудерживающей способностью, и за счет особенности технологии паштетов предварительной тепловой обработки мясного сырья, что придает паштету нежную мажущуюся консистенцию.

Результат дегустации по определению выраженности каждой составляющей вкуса паштета представлен в виде профилограммы вкуса для трех экспериментальных образцов паштета с различным содержанием БМК в рецептуре (рис. 1).

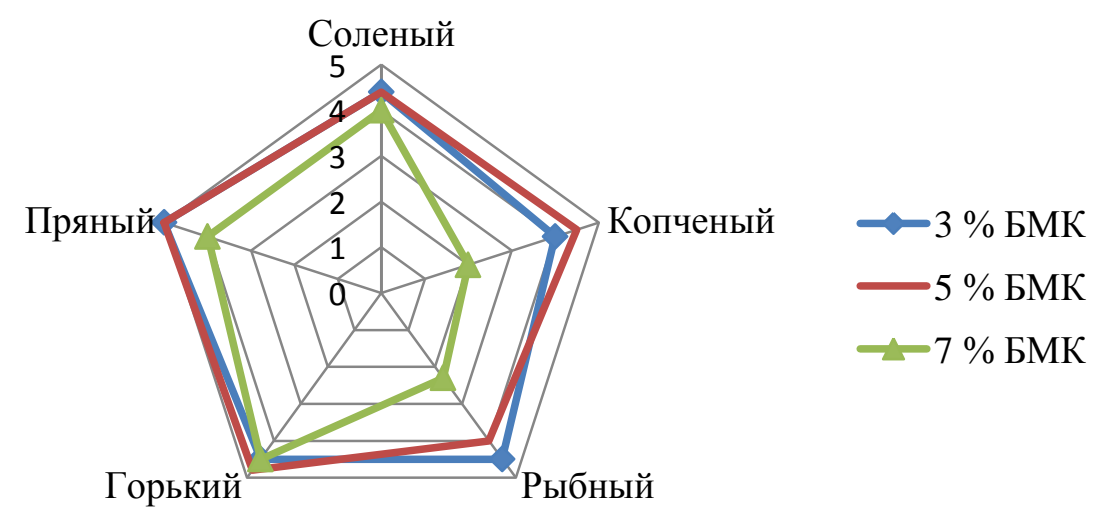

Рисунок 1 - Профиль вкуса образцов обогащенного мясного паштета

В данном случае для расшифровки профиля необходимо применять балловую шкалу, согласно которой проводилась дегустация образцов (табл. 1). Оценка составляющих вкуса дана не по степени их выраженности в продукте, а по оптимальности свойства. Таким образом, чем больше площадь поверхности профиля, тем выше вкусовые качества продукта. Белково-минеральный комплекс является источником копченого и рыбного вкусовых ощущений. На профилограмме видно различие образцов паштета именно по этим составляющим вкуса. При этом стоит отметить, что площадь поверхности профилей для образцов с 3 \% БМК и с 5 \% БМК практически равна, что говорит о высокой оценке их свойств в равной степени, не смотря на некоторые вкусовые отличия.

Таблица 1 - Балловая шкала для оценки интенсивности составляющих вкуса мясного паштета, обогащенного белково-минеральным комплексом, в баллах

\begin{tabular}{|l|ll|}
\hline Сенсорные термины & \multicolumn{2}{|c|}{ Оценка интенсивности } \\
\hline Соленый & 5 - умеренно выраженный & 2 - признак отсутствует \\
& 4 - четко выраженный & 1 - сильный \\
& 3 - едва ощущаемый & 0 - очень сильный \\
\hline Копченый & 5 - умеренно выраженный & 2 - четко выраженный \\
& 4 - едва ощущаемый & 1 - сильный \\
& 3 - признак отсутствует & 0 - очень сильный \\
\hline Рыбный & 5 - признак отсутствует & 2 - четко выраженный \\
& 4 - едва ощущаемый & $1-$ сильный \\
\hline
\end{tabular}




\begin{tabular}{|l|ll|}
\hline & $3-$ умеренно интенсивный & 0 - очень сильный \\
\hline Горький & 5 - признак отсутствует & 2 - четко выраженный \\
& 4- едва ощущаемый & $1-$ сильный \\
& 3- умеренно интенсивный & $0-$ очень сильный \\
\hline Пряный & 5 - умеренно выраженный & 2 - признак отсутствует \\
& 4- четко выраженный & 1 - сильный \\
& 3- едва ощущаемый & $0-$ очень сильный \\
\hline
\end{tabular}

С целью определения оптимального содержания БМК в рецептуре паштета по всем показателям качества на следующем этапе работы была проведена оценка функциональных свойств экспериментальных образцов паштета. Выявлено повышенное содержание кальция в БМК, в среднем составляющее 600 мг/100 г. Сравнительная характеристика образцов по содержанию кальция представлена в табл. 2.

Таблица 2 - Сравнительная характеристика образцов обогащенного мясного паштета по функциональным свойствам

\begin{tabular}{|c|c|c|c|}
\hline \multirow{2}{*}{ Показатели } & \multicolumn{3}{|c|}{ Массовая доля БМК в рецептуре паштета, \% } \\
\cline { 2 - 4 } & 3,0 & 5,0 & 7,0 \\
\hline Содержание кальция в паштете, мг/100 г & 250 & 370 & 490 \\
\hline $\begin{array}{l}\text { Удовлетворение суточной потребности } \\
\text { в кальции в расчете на порцию (50 г), \% }\end{array}$ & 12 & 18 & 24 \\
\hline
\end{tabular}

Согласно понятию ГОСТ Р 52349-2005 «Продукты пищевые. Продукты пищевые функциональные. Термины и определения» функциональным считается пищевой продукт, удовлетворяющий не менее $15 \%$ суточной потребности в функциональном пищевом компоненте в расчете на одну порцию продукта. Таким образом, при стремлении к функциональности продукта рекомендуется введение в рецептуру разрабатываемого мясного паштета не менее 5 \% БМК.

Обогащающим компонентом в рецептуре паштета является продукт переработки сырья горячего копчения. Процесс традиционного горячего копчения рыбного сырья, применяемого в производстве классических рыбных консервов «Шпроты в масле», происходит с обязательным использованием древесного сырья. Продуктами неполного сгорания древесины являются сложные органические соединения, в том числе полициклические ароматические углеводороды (ПАУ). В России и многих других странах в качестве идентификатора присутствия ПАУ выступает бензпирен, наиболее опасный представитель ПАУ. Бензпирен имеет высший класс опасности, обладает свойством биоаккумуляции, оказывает канцерогенное и мутагенное действие на животных и человека. При этом доказано, что токсикологическое действие ПАУ на человека менее значительно, чем на животных, а допустимые уровни бензпирена установлены техническим регламентом и контролируются государством [4]. Согласно техническому регламенту Таможенного союза ТР ТС 021/2011 «О безопасности пищевой продукции» предельно допустимые концентрации бензпирена в продуктах питания составляют не более 0,005 мг/кг для копченой рыбы и не более 0,001 мг/кг для остальной пищевой продукции, кроме продуктов специального назначения. В связи с вышеуказанным важной задачей данной работы стало доказательство безопасности мясного паштета нового вида именно по содержанию бензпирена.

При гидротермолизе голов копченой кильки выход сухого БМК составляет порядка $30 \%$ от исходного сырья. Бензпирен является нерастворимым в воде веществом и слабо растворимым в жирах, в связи с чем основная его часть переходит в БМК и концентрируется за счет высушивания плотной части, остающейся после гидротермолиза голов кильки.

В результате анализа содержания бензпирена в БМК и головах кильки горячего копчения на базе Лабораторного центра «АтлантНИРО» получены следующие результаты: содержание бензпирена в головах кильки горячего копчения составило 0,0063 мг/кг, 
а в БМК - 0,0159 мг/кг. На основе полученных данных рассчитано содержание бензпирена в трех образцах паштета (табл. 3).

Таблица 3 - Сравнительная характеристика образцов обогащенного мясного паштета по содержанию бензпирена

\begin{tabular}{|l|c|c|c|}
\hline \multirow{2}{*}{ Показатель } & \multicolumn{3}{|c|}{ Массовая доля БМК в рецептуре паштета, \% } \\
\cline { 2 - 4 } & 3,0 & 5,0 & 7,0 \\
\hline Содержание бензпирена, мг/кг & 0,0005 & 0,0008 & 0,0011 \\
\hline Соответствие требованиям безопасности & Соответствует & Соответствует & Не соответствует \\
\hline
\end{tabular}

Таким образом, при содержании бензпирена в добавке в пределах 0,016 мг/кг обогащенный паштет, содержащий не более 5 \% БМК, будет содержать не более 0,001 мг/кг бензпирена в соответствии с установленной нормой безопасности по данному показателю.

\title{
ЗАКЛЮЧЕНИЕ
}

На основании проведенной работы можно сделать вывод, что оптимальной для введения в рецептуру паштета будет массовая доля БМК из голов кильки горячего копчения в количестве $5 \%$. Паштет, изготовленный по такой рецептуре, обладает приятными органолептическими свойствами с умеренно выраженными вкусом и ароматом копченой рыбы, является функциональным по содержанию кальция, удовлетворяя порядка 18 \% суточной потребности в данном элементе в пересчете на одну порцию (50 г), и безопасен по содержанию бензпирена в соответствии с требованиями технических регламентов. При этом установлено, что уровень бензпирена в БМК не должен превышать 0,016 мг/кг.

\section{СПИСОК ЛИТЕРАТУРЫ}

1. Единые нормы отходов, потерь, выхода готовой продукции и расхода сырья при производстве пищевой продукции из морских гидробионтов: утв. Госкомрыболовством РФ 29.04.2002.

2. Мезенова, О. Я. Перспективы получения и использования протеинов из вторичного рыбного сырья / О. Я. Мезенова // Вестник Международной академии холода. - 2018. № 1. - С. 5-10.

3. Методика выполнения измерений массовой доли бенз(а)пирена в пищевых продуктах, продовольственном сырье, пищевых добавках методом высокоэффективной жидкостной хроматографии : ФР.1.31.2008.01033 : Свидетельство № 30-08 от 04.03.2008.

4. Бигалиев, А. Б. К вопросу о патогенном действии бензапирена, как загрязнителя окружающей среды (обзор) / А. Б. Бигалиев, А. В. Синтюрина, 3. М. Бияшева // Вестник КазНУ. Серия экологическая. - 2009. - № 1(24). - С. 14-21.

\section{SAFETY OF MEAT PATE ENRICHED WITH PROTEIN-MINERAL COMPONENT OF SECONDARY HOT SMOKED FISH RAW MATERIALS BY BENZPYRENE CONTENT}

\author{
K. A. Stepanova, master student, \\ e-mail: stepanova_kld@mail.ru \\ Kaliningrad State Technical University
}

The article reflects the results of work on the evaluation of samples of meat pate enriched with a protein-mineral component of hot-smoked secondary raw materials. Comparative characteristics of pate samples in terms of organoleptic indicators, functional properties and their safety in terms of benzopyrene content are given. The optimal dosage of the protein-mineral 
complex for introducing pate into the recipe has been determined. The maximum permissible level of benzpyrene in the protein-mineral complex has been established.

Key words: meat pate, protein-mineral complex, calcium, organoleptic parameters, benzpyrene 